\title{
MORE THAN WORDS: DRAMA AND SPECTRALITY FOR THE ARTICULATION OF TRAUMA
}

\author{
Eva Gil Cuder \\ University of Sevilla
}

\begin{abstract}
The anti-logocentric nature of traumatic memory has traditionally brought about the conclusion that there is an indestructible barrier separating trauma from understanding. The impossibility to find the right words to articulate the trauma or for the victim to come to terms with his traumatic experience has generated the assumption that neither witnesses, nor victims will be allowed to access their traumatic history due to its undecipherable character. With this taken for granted belief in mind, this paper analyzes three works by British playwrights Caryl Churchill, Sarah Daniels and Sarah Kane in which the female characters suffer from repeated traumatic regressions. I will argue that trauma finds a most appropriate means of expression in theatrical representation, as the genre allows for alternative means of articulation beyond verbal language and words (which, given their rational and necessarily limited dimension, do not offer a valid solution for the possible formulation of the repressed trauma). These authors evidence that theatrical language offers effective strategies to communicate the experience of trauma and that these antinaturalistic rhetoric seems to be the best response to the chaotic and irrational nature of traumatic memory. ${ }^{1}$
\end{abstract}

Keywords: PTSD (Post-Traumatic Stress Disorder), fantasy, anti-naturalistic aesthetics, traumatic memory, split self.

1 A preliminary version of this article was presented at the International Conference Beyond Trauma: Narratives of (Im)Possibility in Contemporary Literatures in English. University of Zaragoza. March 31, April $1^{\text {st }}$ and $2^{\text {nd }}, 2011$. 


\title{
MÁS QUE PALABRAS: EL DRAMA Y EL ESPECTRO EN LA EXPRESIÓN DEL TRAUMA
}

\begin{abstract}
RESUMEN. La naturaleza anti-logocéntrica de la memoria traumática tiende a generar la conclusión de que existe una barrera indestructible que separa el trauma del entendimiento. La imposibilidad de encontrar las palabras adecuadas para formular el trauma, o para que la víctima asimile la experiencia traumática, ha suscitado la creencia de que ni los testigos ni las victimas directas pueden tener acceso a su historia traumática como consecuencia del carácter indescifrable de la misma. Partiendo de esta idea, este artículo analiza tres obras escritas por las autoras británicas Caryl Churchill, Sarah Daniels y Sarah Kane en las cuales los personajes femeninos sufren repetidas regresiones traumáticas. A partir de dicho análisis, se defiende que la representación teatral constituye un medio apropiado para la expresión del trauma, ya que el género teatral permite trabajar con fórmulas alternativas de expresión que van más allá del lenguaje verbal y de las palabras (las cuales, dada su dimensión racional y necesariamente limitada, no ofrecen una solución válida para una posible formulación del trauma reprimido). Estas autoras ponen de manifiesto que el lenguaje teatral ofrece estrategias efectivas en la comunicación de la experiencia traumática, y que dicha retórica antinaturalista parece ofrecer la mejor respuesta ante la naturaleza caótica e irracional que caracteriza a la memoria traumática.
\end{abstract}

Palabras clave: PTSD (Síndrome de Estrés Post-Traumático), fantasía, estética anti-naturalista, memoria traumática, disociación del yo.

Received 15 February 2012

Revised version accepted 02 May 2012

Contemporary narratives show a growing interest in the representation of post-traumatic conditions and in the healing process that follows a traumatic event. There seems to be an inclination to represent the reenactment of trauma as imaginary, hallucinatory and as infiltrating into the affected subject's everyday life in such a way that it becomes almost impossible to tell which experience is genuine and which is a fallacy. Contemporary media is focusing its attention on this kind of representation of trauma and on the analysis of how the affected subject reacts to traumatic reenactment by looking for reparation in a different realm. Recent popular films such as Pan's Labyrinth (2006) or Inception (2010) represent the attempt to escape from traumatic recollection through the construction of an alternative dimension where the subject can lead an invented life which helps him avoid the revisitation of the trauma or which allows him to come to terms with a difficult past. Nevertheless, the subject realizes that it is 
impossible to escape from traumatic memory, and even in this fictitious realm, he finds himself being chased by the recollection of the traumatic event, which reappears in the form of grotesque, or ghostly presences. This device is part of a broader convention in contemporary narrative that attempts to represent traumatic memory by associating it with the illusive, the indefinite and the unstable. Trauma is, thus, dissociated from the rational and the analytical as well as from the logocentric, since the use of verbal language alone seems to be discredited in its potential to articulate it. In this paper, I will analyze some of these representational devices that are used for the formulation of trauma, and, in relation to this, I will try to demonstrate how theatrical representation is produced as a literary genre suitable for the expression of traumatic memory. For that purpose, I will concentrate on the work of three British playwrights, Caryl Churchill, Sarah Daniels and Sarah Kane, who formulate the traumatic memory of female characters by means of literary strategies that break with the verisimilitude and the reality effect in their plays, and so match the unintelligible nature of trauma.

In Caryl Churchill's The Skriker (1994), the author analyzes the question of the involuntary recollection of the traumatic event, and how the subject suffering from what in clinical terms has been called Post Traumatic Stress Disorder $(\mathrm{PTSD})^{2}$ is condemned to a life where her every day routine coexists with the unexpected and unpleasant reenactment of the traumatic event. Belatedness and latency are considered as two of the defining symptoms distinguishing PTSD, as the trauma reappears unexpectedly and intrudes into the victim's everyday life by means of flashbacks, nightmares, phobias, or any other process that escapes the patient's control (Caruth 1995: 151-154). Traumatic memory works in an unpredictable way: the trauma is elicited and reenacted unexpectedly some time after the traumatic event has taken place, thus haunting the victim until it can be assimilated and incorporated to narrative memory. In Churchill's play, two young girls, Josie and Lily, are disturbed by the presence of a ghostly figure, the Skriker, who is described in the stage directions as "a shapeshifter and death

\footnotetext{
2 Post Traumatic Stress Disorder (PTSD) was first registered as a mental illness in the 1980 edition of the Diagnostic and Statistic Manual of the American Psychiatric Association. The group of symptoms there numbered for its identification are related to the different ways in which the traumatic event may be re-experienced by the victim: nightmares, intrusive flashbacks, dreams and reenactments of the original event. This classification of PTSD as a detectable mental disorder originated its departure from an earlier inclination to associate the term with mental states caused by war injuries and war experiences. Nowadays, the term is widely accepted as a mental disorder diagnosed to "[i]ndividuals who experience wars, disasters, accidents or other extreme 'stressor' events [that] produce certain identifiable somatic and psycho-somatic disturbances" (Luckhurst 1)
} 
portent" (Churchill 1998: 243). This specter-like being inhabits an underworld that represents traumatic memory, since it functions as the place where all the disturbing memories of the two female characters coexist. The Skriker, this ghostly character, haunts the two female protagonists trying to seduce them so as to take them to the underworld, where the traumatic event will be reenacted. The illusory and phantasmagoric nature of the Skriker, being a vision which appears unexpectedly, intruding upon the lives of the two female protagonists, coincides with what psychoanalysts Nicolas Abraham and Maria Torok would classify as fantasy. ${ }^{3}$ In The Shell and the Kernel (1987), Torok and Abraham provide a thorough definition of fantasy, distinguishing this phenomenon from others that are prone to be confused with it such as hallucination, imagination or delusion. They argue that fantasy is a worthy instrument therapists have in order to access a patient's mind and to identify a possible fissure caused by a traumatic event: "Fantasy can become a readable entity, paving the way for the free verbalization of desires, affects or conflicts that, without the mediation of dreams and fantasies, would have remained inaccessible and unexpressed" (1994: 25). According to their work, fantasy is "an unreal mental image or vision that is immediately recognized as such by the ego" (1994: 24). However, they contend that the patient's ego is not fully responsible for the apparition of such visions, and remains a mere witness to what is being experienced by the subject. Therefore, such apparitions are not devised by the ego and fantasies are not deliberate visions but involuntary and unexpected episodes that fall out of the control of the patient's ego. Thus, in Churchill's The Skriker, this ghostly apparition eliciting Lily and Josie's inner trauma coincides with what Torok and Abraham esteem as a fantasy, as it appears unexpectedly and is not provoked or aroused by these two characters' imagination. On the contrary, the two female protagonists become victims to the Skriker's apparitions, which haunt them with the reminiscence of the traumatic situations they have gone through in the past.

The Skriker was the least successful of Churchill's plays, probably due to its abstract and non-realistic nature, which contrasts with her previous political work (Cloud Nine in 1979, Owners in 1982, Soft Cops in 1984, etc.). According to Aston (2003: 20), critics were especially hostile to the physical representation of the underworld because it distorts the reality effect of the play (28).

\footnotetext{
3 Maria Torok (1926-1998) and Nicholas Abraham (1919-1975), both Hungarian-born French psychoanalysts, worked on a critical study of Freud using present notions about transgenerational trauma and fantasy as instruments for therapy. Their study and elaboration on Freud's work was published in their two works The Wolf's Man Magic Word: A Cryptonymy (1986) and The Shell and the Kernel (1987).
} 
Nevertheless, it is precisely this abstract and non-naturalistic description of the underworld what makes of it such an appropriate instrument to identify and describe the characters' traumatic history. This is the case with one of the scenes in the play where one of the protagonists, Josie, is persuaded by the Skriker to descend to the underworld. ${ }^{4}$ There, she reenacts the event causing her mental breakdown: at the very opening of the play, we found Josie hospitalized in a mental institution for having committed infanticide. Therefore, it is the very image of her baby that haunts her once she descends to the Skriker's world. ${ }^{5}$

Josie's re-experiencing of the traumatic event when she descends to this realm is an example of how this anti-naturalistic convention (the coexistence of real life and the underworld in Josie's mind) works as a strategy that makes visible the repressed state of shock affecting the characters. This representation of the underworld as immaterial and irrational and its intrusion into the characters' real lives stand for the intrusion of elements from the traumatic event into the victim's everyday life. In the play we constantly encounter episodes where the Skriker appears which work as a reminder that the threat of the latent trauma to be aroused is always present. The inability to separate real life from the Sckriker's world is symbolic for the paradox of how traumatic memory works in the subject's mind. The subject affected by the traumatic event is unable to assimilate and incorporate the trauma into his mental schema, but then he is also unable to get rid of it, since it reappears unexpectedly, being triggered by external stimuli. In The Skriker, this paradox is further represented by having the characters collapse at the inability to understand whether they are living a real experience, or a nightmare:

LILY: This is a dream. It's a nightmare and I'll wake up. I know I think other things happened like the money but that's because I'm remembering it in the dream.

JOSIE: It's not a dream. She made me/ speak toads.

LILY: You would say that just because you're somebody in my dream.

JOSIE: I'm not, it's me, I'm awake.

[...]

LILY: I can't wake up yet but I can make it stop being a nightmare.

\footnotetext{
4 This descent of the main character to a terrifying, ghostly reality can be read as a postmodern rewriting of the traditional motif of the visit to the underworld found in classics such as Dante's Divine Comedy, Homer's The Aeneid, or in religious mythology (the myth of Orpheus and the myth of Ishtar).

5 The echo of Toni Morrison's Beloved (1987) is too evident to go unnoticed. The novel is set in the late nineteenth century, just after the American Civil War, and tells about a mother (Sethe) who kills her own daughter rather than allow a posse to take her as a slave. The daughter will later on return in the form of a ghost and haunt the place where she was killed, thus preventing the traumatic event from being forgotten.
} 
JOSIE: Lily-

LILY: I wish for flowers.

Flowers fall from above. SKRIKER takes LILY's hand and puts it against her face (Churchill 1998: 262).

In this sense, the intermingling of both spheres, real life and the underworld, stands for the intrusion of the distressing memory into the subject's quotidian existence after the traumatic event.

The incomprehensibility and the incommensurable nature of traumatic memory are further represented in the play through the language used by the Skriker. Its broken and indecipherable syntax, its incoherence and the use of a kind of linguistic pattern based on sounds and repetitions that render the lines almost incomprehensible represent the language of the repressed, associated to the realm of the semiotic. The audience witnesses the attempt to articulate the trauma and the inability to do so:

SKRIKER: Don't get this ointment disappointment in your eyes I say to the mortal middlewife but of course she does and the splendoured thing palace picture palace winter policeman's ball suddenly blurred visionary missionary mishmash potato, and there was a mud hit mad hut and the mother a murder in rags tags and bob's your uncle and the baby a wrinkly crinkly crackerjack of all trading places, because of course it was all glamour amour amorphous fuss about nothing (Churchill 1998: 245).

This represents the impossibility to find the words to explain in a rational way (the symbolic realm) what the ineffability of trauma consists of. ${ }^{6}$ As Caruth says in Trauma: Explorations in Memory, "the attempt to gain access to a traumatic history [...] can only be perceived in inassimilable forms" (1995: 156), and it is in this sense that Churchill plays with language here. Her play offers different attempts to access the victim's traumatized psyche, one of them being the Skriker's language. However, it proves to be a rather limited instrument for the recuperation and articulation of traumatic memory, as the Skriker's language only grants partial information of the initial traumatic event (how Josie killed her own baby).

The unexpected intrusions of the Skriker are symbolic for the dissociative state of the two protagonists after the traumatic event (how they are unable to

\footnotetext{
6 The Skriker's language resorts to means that highlight the form of language, overlooking the content and the sense made of the actual words uttered. Devices such as alliteration, eye rhyme, syntactic repetition and internal rhyme attest for an inclination towards a visual and sensorial kind of speech in this attempt to formulate the trauma, thus disadvantaging the symbolic, logocentric order and favoring the semiotic realm or imaginary order.
} 
discern between real existence and the reenactment of the traumatic memory). Moreover, as the plot focuses on the two main characters' perspective, the audience experiences these two levels of "reality" and so they are also made to question the extent to which Josie and Lily's experiences are real or just a reenactment of the trauma. This is the effect by which Churchill manages to articulate the chaotic and uncertain nature of the traumatic memory reenacted by a subject suffering from PTSD. The Skriker's frustrated attempt to formulate the trauma through verbal means becomes an example of the ineffability that characterizes traumatic memory and that renders it inaccessible through rational means such as verbal language.

For Caruth, when the victim attempts to express trauma, there exists the risk of "losing the precision and the force" of the original experience of the traumatic event (1995: 153), and it is precisely here where the importance of language in Trauma Studies comes into play. She talks about the "danger of speech" when dealing with the integration of traumatic memory into narrative memory, arguing that traumatic memory works irrationally and that by bringing some logic or order into it, we may be destroying its truth, and here lies the essential paradox of trauma articulation:

The trauma [...] requires integration, both for the sake of testimony and for the sake of cure. But [...] the transformation of the trauma into a narrative memory that allows the story to be verbalized and communicated may lose both the precision and the force that characterizes traumatic recall (Caruth 1995: 153).

Caruth maintains that "the impossibility of a comprehensible story [...] does not necessarily mean the denial of a transmissible truth" (1995: 154). Therefore, she is arguing in favor of a form of transmission of the traumatic memory where the latter is not distorted by the logic of certain elements (such as speech) that might deprive it of its original truth and authenticity:

The danger of speech, of integration into the narration of memory, may lie not in what it cannot understand, but in that it understands too much. Speech seems to offer only [...] the attempt to move away from the experience of shock by reintegrating it into a stable understanding of it (Caruth 1995: 154).

This same notion of speech being insufficient to express the authenticity of inner trauma is presented by Sarah Daniels in Beside Herself (1990). Here, the repressed trauma is personified as a character in the play, Eve, who gives voice to the main character's traumatized psyche and inner thoughts. Thus, the author introduces the notion of the "split self" by the doubling of the main character, Evelyn, who splits into two beings at the very opening of the play, her alter ego 
being Eve. ${ }^{7}$ Eve appears in every scene next to Evelyn and her words attempt to utter that which Evelyn is unable to formulate (her real thoughts about the other characters or the truth about her traumatic past, which is buried and repressed somewhere in her inner psyche). Eve constantly demands Evelyn to disregard the social repercussions that her confession would provoke (her father is a prominent doctor and her husband is a Member of Parliament) and to find the strength to tell about the abuses she was victim of as a child:

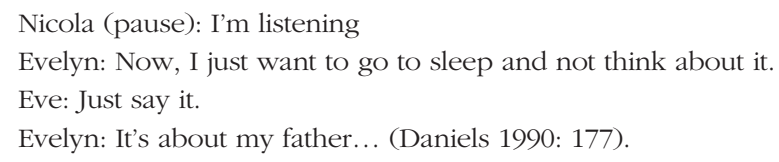

However, speech appears again as an insufficient means for the reconstruction of the traumatic event, since Eve herself, despite finding no social restrictions impeding the formulation of what happened, is not able to find the words to articulate the trauma and she also experiences episodes of collapse, as made explicit by stage directions: "Eve curls up, knees under chin, head down covered by her arms" (Daniels 1990: 59).

The notion of doubling one's identity takes us back to Lacan (1953) and his mirror stage concept by which he argued that there is a stage in the psychological development of a child where he discovers his own reflection in the mirror and becomes aware that there is a social self which goes beyond his own recognition of selfhood. This is the moment "that will henceforth link the I to socially elaborated situations" (Lacan 1953: 5). In Beside Herself, the analysis of the two female characters in terms of their naming can already reveal part of what their function in the play is: 'Eve' can be considered as short-name for 'Evelyn', just as the character itself works as a kind of child-like Evelyn whose personality is incomplete and not well developed into the adult, social world. The ghostly apparition of Eve in the play, therefore, becomes an indication that, due to Evelyn's traumatic childhood, she was never able to go through the 'mirror stage' and accept her own existence as a social being. This 'mirror stage' is a necessary step every individual needs to go through as a child so as to become a social being and reach psychological maturity. However, and due

\footnotetext{
7 A similar strategy to represent trauma is found in Debbie Tucker Green's Stoning Mary (2005), where two of the main characters, addressed as "husband" and "wife", have an alter ego that they alone can see. In a similar way to Eve in Beside Herself, the alter egos of "husband" and "wife" speak out their minds and are able to say out loud what the real wife and the real husband are not able to utter.
} 
to her traumatic childhood, Evelyn has not gone through this self-acceptance stage and that is the reason why, as an adult, she develops this alter-ego (Eve) that is now trying to force her to assimilate the traumatic event and to finally undergo this self-recognition stage.

This psychological process is thus represented in the play by the apparition of this imaginary character, Eve, and by the doubling of the action, which creates two onstage levels of reality (the external reality and Evelyn's inner psychological struggle). But Daniels (1990) also resorts to some other theatrical devices for the representation of Evelyn's traumatic mental state. The recurrent use of a broken mirror onstage is symbolic for Evelyn's mental state: her psyche or her inner self is completely destroyed and shattered to pieces, as she has never been able to assimilate (not even to acknowledge or to recall) the sexual abuses she was victim of as a child at the hands of her own father. This traumatic situation hindered Evelyn from going through this self acceptance step or 'mirror stage', as she kept denying the reality that surrounded her, and so her inner self remained broken and fragmented all this while, which is as well represented by the presence of Eve onstage. Eve appears as the personification of Evelyn's traumatized psyche due to her childhood trauma.

As the traumatic situation described in Beside Herself is child abuse, the play focuses the action on Evelyn, her relationship with her father, and the social work she feels obliged to fulfill as the wife of an MP. Evelyn meets Nicola, the other incest victim in the play, at the community group home where she volunteers, although they do not become close enough "so as to deal with therir traumatic past" and barely exchange a word until the end of the play. Nicola and Evelyn's mutual support follows an already established pattern of female paired friendships that was also to be found in The Skriker, as well as in many other plays by Churchill and other female playwrights. It consists of having two similar stories develop in a side by side manner so that the two feminine protagonists of each parallel story can provide mutual care and protection against patriarchy and a male dominated world. ${ }^{8}$ In Beside Herself, it is Nicola who helps Evelyn gain a lucid recollection of the traumatic event. Up to this point, Evelyn had tried to carry on as if nothing had happened (Daniels 1990: 56), but the 'ghost' of her father's transgression haunted her wherever she went in the form of Eve.

\footnotetext{
8 Timberlake Wertenbaker's The Love of a Nightingale (1988) is another example of this. Procne and Philomele, the two protagonists of the play, are two sisters who rebel against the impositions of a male dominant character, Tereus, who is married to Philomele and rapes Procne when he is taking her to see her sister.
} 
Accordingly, Eve plays a similar role to that of the Skriker in Churchill's play. She reminds Evelyn of what causes her mental instability and restlessness. She works in the exact same way as traumatic memory does in real PTSD cases: the patient will not assimilate the trauma, as it is not possible to formulate it in a rational manner (thus, Eve is the expression of it in an abstract way), but he cannot escape the recollection of it either, since it follows him and reappears when induced by external stimuli. This paradoxical process of not being able to forget, yet not fully remembering either is symbolized by the broken mirror in the living room of the community house:

Lil Unnerving, ain' t it- how you can only see a piece of yourself in a shard of mirror. It's sort of like trying to recall a dream when you can only visualize the bit that woke you up (Daniels 1990: 12).

Apart from being an explicit reference to Lacan's (1953) 'mirror stage', Daniels (1990) also uses the mirror in the play as a means to reveal how Evelyn shows absolute resistance to the recollection of the traumatic event. When she comes into the livingroom and faces her shattered reflection in the broken mirror, she likes what she sees, as if she was at ease with having just a partial view of her own reflection and did not need (or was trying to avoid) having a complete picture of herself. Here, Eve is representing again her alter ego, giving voice to her repressed subconscious:

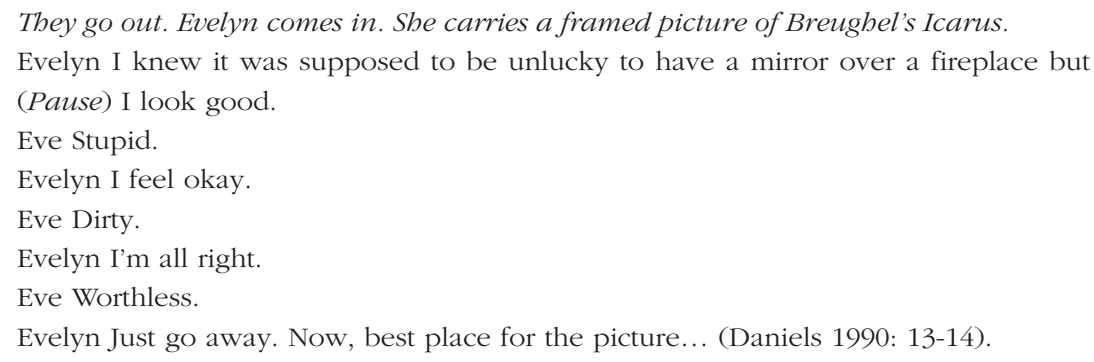

Evelyn's attempt to silence the voice of the repressed ("go away") indicates that she does not want to face the traumatic memory. Moreover, she utters out loud affirmative statements ("I feel okay [...] I'm all right") to convince herself that she is fine, when actually she is not. Thus, she is not only trying to avoid the reenactment of the traumatic event, but she is also hiding it under the false pretense that everything is all right. In this sense, and as argued above, Eve's status as representing Evelyn's inner ego before going through the 'mirror stage' is reinforced: she does not regard social rules of politeness but states any thought 
crossing her mind. As a consequence of not having any sense of social behavior, Evelyn lacks the ability to deal with her feelings when in a social environment. This is especially made visible in the scene where she finds the dead body of Dave, one of the patients living in the community house. While Evelyn, too centered on not being judged, is only worried about the impression that finding a dead body would cause on the neighbors visiting the community center, it is Eve the one that notices the dead body and alerts Evelyn, who remains untouched and unresponsive:

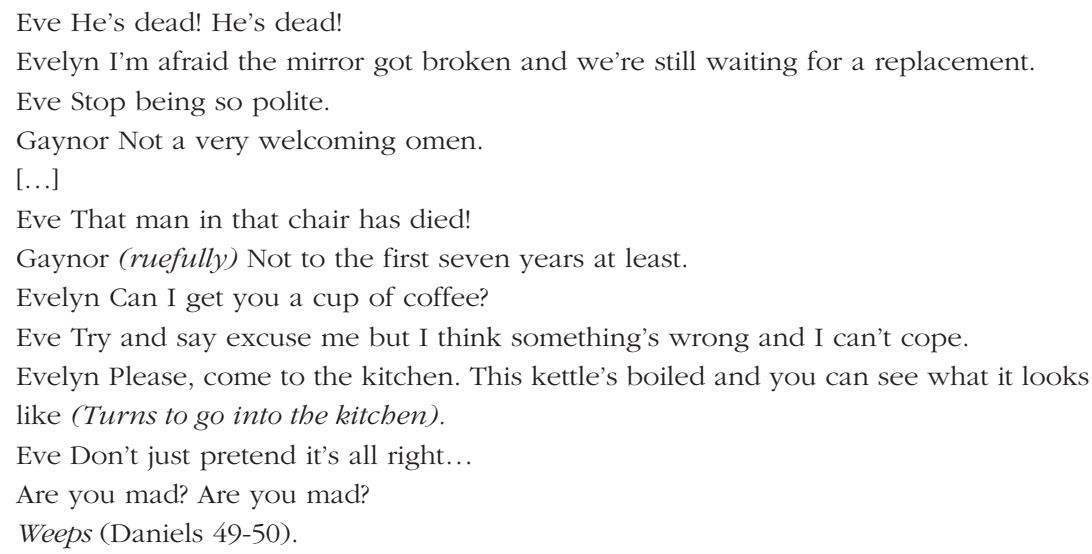

Along with the notion of fragmented memory represented through the broken mirror (Daniels 1990: 13), the idea that memory is whimsical and inaccessible also becomes recurrent in the play: "Dave I'm sure half my life has been wonderful. I just can't remember it" (Daniels 1990: 38), or "Lil ...Silly the things you remember" (Daniels 1990: 41). As Van der Kolk and Van der Hart (1995) argue, it is necessary for the victim of a traumatic event to incorporate the traumatic recollection into the already existing mental schema or narrative memory, since "the mind organizes new sensory information into preexisting patterns" (170). The role that Eve plays in Evelyn's case is precisely that of integrating Evelyns memory of the repressed trauma to her pre-established pattern of memories and past experiences, since that is the only way for her to incorporate the recollection of the traumatic event. Eve's role is that of smoothing the transition that would transform Evelyn's traumatic memory into narrative memory. In this sense, Eve becomes the voice of an inner mental wound trying to cry out the truth of the latent trauma repressed by Evelyn's ego. As Caruth argues, "it is always the story of a wound that cries out, that addresses us in the attempt to tell us of a reality that is not otherwise available" (1996: 4). Silence is 
one of the symptoms undergone by the victim of a traumatic event, as the latent trauma needs to be articulated (that inner voice needs to be heard and made sense of) so that the trauma can be assimilated, but no means are found for an accurate formulation. All of the characters in the play who have been victims of a traumatic event undergo a period of silence in which the trauma does not find a way out to be expressed. Thus, Nicola does not speak to her mother (whom she accuses of not having helped her out when she started being abused by her stepfather), Evelyn refuses to remember (and, thus, to speak about) her father's transgressions towards her when she was a child (Eve represents that inner part of Evelyn trying to voice the trauma) and Dave, the only trauma victim in the play who is under treatment, talks about a period in his life when he remained silent and refused to speak, since his own words could be used against him by the medical doctors treating him:

Dave Under the scrutiny of the psychiatric profession each syllable is weighted, waiting to be labeled before it's even uttered. Such meaning is heaped upon the spoken word that one becomes too inhibited to perform the act (Daniels 1990: 38).

Silence is indicative of the ineffability characterizing traumatic memory and has probably been one of the strategies most frequently used in drama when dealing with trauma and the problems faced when trying to formulate it. Sarah Kane's play, Cleansed (1998), takes the notion of silence to its extremes to the point that one of the traumatized characters in the play is mutilated so that first it is his tongue that is ripped off (so that he cannot speak), and then any of his body parts by which he attempts to communicate his feelings (his hands, when he tries to write, and his feet, when he tries to dance). In this sense, the play may be regarded as a revisitation of Ovid's myth about the two sisters, Procne and Philomele, in which Tereus, Philomele's husband and king of Thrace, cuts off Procne's tongue after raping her so she remains silent and is unable to

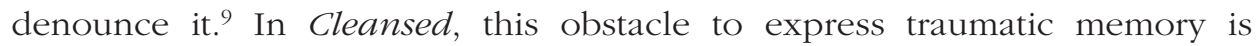
overcome by the appearance of spectral figures whose function is precisely that of finding a means of expression to the repressed trauma. Therefore, just like Eve

\footnotetext{
9 The myth of Procne and Philomele is depicted by Ovid in his Metamorphosis. It tells the story of the two sisters, one of them married to Tereus, king of Thrace. Procne, the youngest sister, is raped by Tereus when he was taking her to visit her sister and, afterwards, he cuts off her tongue. In Cleansed, Sarah Kane borrows some of the facts told by Ovid, such as the amputation of a character's tongue. The Love of a Nightingale (1988) by Timberlake Wertenbaker is another rewriting of the myth, dealing also with the notion of silence and frustration at the impossibility to verbalize the traumatic memory of a female character that has been abused.
} 
and the Skriker in the plays analyzed above, Cleansed introduces another ghostly and spectral vision, Graham, that can only be seen by one of the traumatized characters in the play, Grace, and which functions as an alternative means for the formulation of trauma, given the impossibility to articulate it by means of words. The appearance of a ghostly presence on stage, that only the traumatized character can see, functions as another anti-naturalistic element that breaks with the realism in the play and allows the audience to have access to the protagonist's distressed mind. This spectral character, that is not 'real' within the fantasy of the theatrical representation, works as an alternative means to articulate the trauma. In this sense, by breaking the reality effect in the play, the playwright is able to transmit her message beyond what the character's mental breakdown allows. And it is in this way that the relationship between Grace and Graham develops as pure fiction within the theatrical illusion: the play opens with the scene in which Graham dies of an overdose and then shows Grace, Graham's sister, arriving at the center where Graham remained hospitalized. The relationship established between the two siblings (or rather, between Grace and the specter of her brother Graham) reminds of the main action in Shakespeare's Twelfth Night, where a brother and a sister lose each other after a shipwreck that takes them both to the same town. Cleansed shows a sister that has also lost her brother (and is also, somehow, looking for him) and who decides to wear his clothes, just like the female character in Twelfth Night wears men's clothes and behaves like a man to be able to carve out a future for herself.

Kane (1998) resorts to the rewriting of classical works as a means to give voice to the female perspective in a story, a perspective which has been silenced so far by the predominant masculine point of view. The use of the myth of Procne and Philomele explicitly appeals to the devoicing of the female perspective in the original, as Procne's tongue is cut by Tereus. In this way, the rewriting of classical works functions as a means to voice female trauma, which had been silenced in the original work. In Cleansed, Kane (1998) also makes good use of the anti-naturalistic component, as it is by haunting and ghostly figures like Graham (which has a similar function to that of Eve and the Skriker from the plays analyzed above) that she manages to formulate the traumatic memory of the female protagonist:

Grace is lying in bed...Graham is sitting at the end of the bed. He smiles at her. Graham Hello, sunshine.

Silence. Grace stares at him. She smacks him around the face as hard as she can, then hugs him to her as tightly as possible. She holds his face in her hands and looks closely at him.

Grace You're clean. 


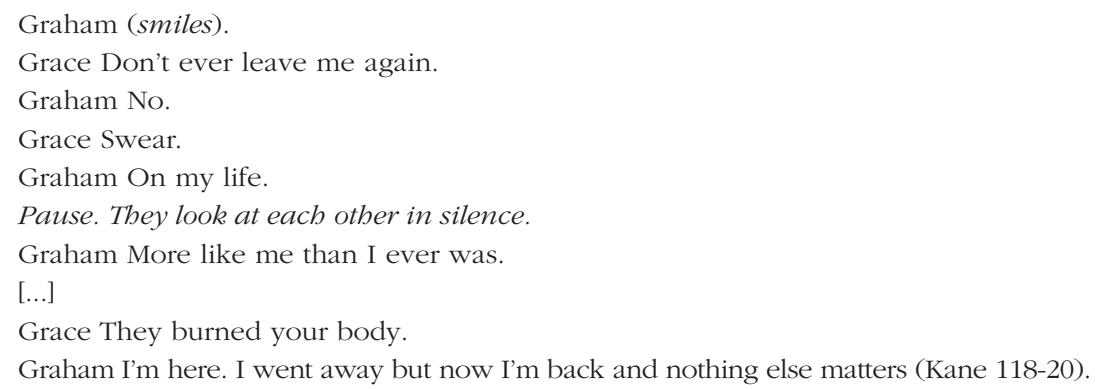

In his analysis of Torquato Tasso's Gerusalemme Liberata and the story of the 'crying wound' that we find in Beyond the Pleasure Principle, Freud tried to illustrate the functioning of belatedness in traumatic memory (Caruth 1996: 8). In Tasso's story, Tancred, the hero, kills his beloved, Clorinda, by accident in a duel and, moved by his rage after finding this out, he slashed a tree with his sword being ignorant that Clorinda's soul was imprisoned in that very same tree. It was only after he could hear his beloved's soul cry after this second attack that he understood what he had done. And it was just then that he could hear the cry of this wound inflicted upon his beloved that he realized about the wound in his own mind. The voice of Clorinda's injured soul became, in this way, Tancred's own inner voice that would not let him forget what he had done. Similarly, Eve in Beside Herself becomes a 'crying wound' too, one that would not let Evelyn forget about her father's transgressions against her and which, just as Clorinda's voice, "represents the other within the self that retains the memory of the 'unwitting' traumatic event of one's past" (Caruth 1996: 8). The Skriker in Churchill's play reappears time and again to remind Josie that she had murdered her own baby, just as Graham in Cleansed comes back in the shape of a ghost that will never allow Grace to forget about his terrible death of an overdose. In conclusion, Eve in Beside Herself, the Skriker in Churchill's play and Graham in Cleansed (the first an imaginary vision, the Skriker a 'death portent' and Graham a ghostly presence) appear as forms of expression by which traumatic memory is articulated. These specter-like characters dismantle the reality effect of the play due to their irrational and non-naturalistic nature, and, as a consequence, they prove to be efficient tools for the reconstruction of trauma in the mind of the affected characters and for its delivery to a major audience. This literary strategy that brings a specter on stage to expose the inner thoughts and fears of the main characters is not only a classical dramatic device as old as theatre itself, but also an adequate means to provide a picture of a subject's traumatic history. The unrealistic nature distinguishing this device makes of it an appropriate tool to give voice to the irrationality that characterizes the 'crying 
wound' or traumatic memory. In this sense, both Churchill (1996, 98, 84) and Daniels (1990) manage to challenge Lacan's (1953) well-known logocentric approach to representation, which advocates for the supremacy of speech as the original signifier of meaning. Moreover, by breaking with these assumed notions on representation, these female playwrights produce an antiphallogocentric narrative in which the characters construct a feminine reality that dismisses the so far predominantly masculine nature of representation, thus inserting themselves within the paradigm of contemporary feminist drama which has explicitly developed alternative and revealing approaches to feminine traumatic history.

\section{REFERENCES}

Abraham, N. and M. Torok. 1994. The Shell and the Kernel. Vol. 1. Chicago: University of Chicago Press.

Abraham, N. and M. Torok. 2005. The Wolf's Man Magic Word: A Cryptonymy. Minneapolis: University of Minnesota Press.

American Psychiatric Association. Diagnostic and Statistic Manual of Mental Disorder. 1987. 3 ed. Washington D.C.: APA.

Aston, E. 2003. Feminist Views on the English Stage: Women Playwrights 19902000. Cambridge: Cambridge University Press.

Caruth, C. 1996. Unclaimed Experience: Trauma, Narrative and History. Baltimore: The John Hopkins University Press.

Caruth, C. ed. 1995. Trauma: Explorations in Memory. Baltimore and London: The John Hopkins University Press.

Churchill, C. 1984. Soft Cops. London: Methuen.

Churchill, C. 1996. Plays: Caryl Churchill. London: Methuen.

Churchill, C. 1998. Plays: Three. London: Nick Hern Books.

Daniels, S. 1990. Beside Herself. London: Methuen Drama.

Freud, S. 1961. Beyond The Pleasure Principle. New York: Norton and Company. Inception (video) 2010. Warner Bros Pictures, Germany.

Kane, S. 2001. Complete Plays. London: Methuen.

Lacan, J. 1953. Écrits: A Selection. New York, London: W.W. Norton and Company.

Morrison, T. 2005. Beloved. London: Random House.

Ovid. 2004. Metamorphosis. New York: Norton and Company. 


\section{EVA GIL CUDER}

Pan's Labyrinth (video) 2006. Esperanto Films, Mexico D.F.

Shakespeare, W. 1994. Twelfth Night. New York: Washington Square Press.

Tucker Green, M. 2005. Stoning Mary. London: Nick Hern Books.

Van der Kolk, B. A. and O. Van der Hart. 1995. "The Intrusive Past: The Flexibility of Memory and The Engraving of Trauma". Trauma: Explorations in Memory. Ed. Cathy Caruth. Baltimore and London: John Hopkins University Press.

Wertenbaker, T. 1996. Plays One: Introduced by the Author. London: Faber and Faber. 